\title{
Foreign Language Requirements For Business Students: An Update
}

Tom Moore, (E-mail: Tom.moore@gcsu.edu), Georgia College \& State University Mehenna Yakhou, Georgia College \& State University

\begin{abstract}
Most undergraduate students who study business in the United States are not required to learn a foreign language at their college or university. The overwhelming majority of Business School deans at both AACSB and non-member schools believe in the usefulness of foreign language study. Furthermore, the AACSB has mandated that global and cultural diversity become part of the business curriculum. However, over the past seven years, these survey results find that business schools have not increased the requirements for foreign language courses at all.
\end{abstract}

\section{INTRODUCTION}

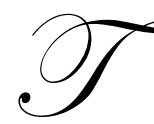

he AACSB requires that undergraduate business majors are exposed to multi-cultural and diversity issues. Furthermore, the preamble of the accreditation standards of the organization requires students to have the necessary education to react to strong and growing international economic forces, to understand differences in organizational and cultural values, to be exposed to cultural diversity among employees and customers, and to be trained in the changing technology. Thus, three of the four expressed educational standards of the AACSB deal with cultural and ethnical diversity.

The U.S. workforce is increasingly being engaged in a more diverse market place. Many of the products we purchase were produced overseas. Many U.S. corporations continue to expand into emerging markets. Domestically, over 46 million American consumers speak languages other than English at home (U.S. Census Bureau, 2003). Therefore, an understanding of cultural differences seems fundamental to everyone having a connection to commerce.

Many commentators have opined that the most fundamental way of achieving an awareness of another's culture is to study and understand other languages. The reluctance of schools in the United States to stress the importance of foreign language study has produced many warnings. As far back as 1979, President Carter's Commission on Foreign Languages and International Studies stated: "Our gross national inadequacy in foreign language skills has become a serious and growing liability."

Little empirical research has focused on the requirements for foreign language study for students majoring in business in colleges and universities in the United States. The focus of this study is to examine foreign language requirements within schools of business, both AACSB members and non-members, in the United States. Also, the study examines the opinions of Business School deans and division heads regarding the importance of foreign language study. Finally, the research seeks to determine if any progress on this issue has been made in the past few years.

\section{LITERATURE REVIEW}

Many commentators have discussed the importance of foreign language study. Timpe (1989) has suggested that certain languages will become central to future international commerce, with the most important being the Asian languages. With the increased rate of globalization, Guy (1992) has argued that efforts to increase foreign language competence are inadequate in the United States. Slonaker and Cannon (1992) have reported that the study of foreign 
language for business students will not become common until the business schools or the AACSB become active in setting objective standards for foreign language study.

Johnson (1993) found that recent business graduates feel that their academic preparation necessary for understanding foreign cultures is inadequate. Koch (1995) found that, even at the graduate level, surveys of business leaders indicated the need for an international component of the MBA program including foreign language requirements.

There are few empirical studies which have attempted to examine foreign language requirements for business students. Radebaugh and Shields (1984) found that in their study of 97 universities with international business majors, only $23 \%$ of the schools required international business majors to study a foreign language; $73 \%$ of the schools considered fewer than 1 in 5 of their international business majors fluent in a foreign language.

The most recent survey of language requirements at Schools of Business is found in the work of Rogers and Arn (1998). Through the use of a survey questionnaire sent to deans at AACSB member schools, the authors found that over one-half (54\%) of accredited schools did not require any foreign language of their business majors. Yet, over $71 \%$ of the deans at these accredited schools believed their school needed the requirement. Spanish, Japanese, and Chinese were considered the most beneficial languages for a student to study. Over $29 \%$ of the Schools which did not have a language requirement standard were studying the feasibility of implementing a language requirement. Overall, many deans were optimistic that language requirements would be implemented within the next few years. In an effort to increase the rate of adoption of a language standard, the authors suggested that AACSB schools should consider adding a one year requirement for foreign language study.

\section{METHOD}

Data were gathered by using a survey questionnaire which was mailed in the early part of 2005 . Thus, seven years have passed since the Rogers and Arn (1998) results were published. We thought that this time period was sufficient to determine if schools which were considering implementing the language requirement back in 1998 had actually done so. The survey was screened by four faculty members within the school of business at Georgia College \& State University and two business deans. The questionnaire and cover letter were sent to the 660 United States Colleges and Universities which maintain a membership with the American Accounting Association. The letter was addressed to the Business Dean or Business Department Head at these schools. This sampling method allows us to consider both AACSB members and non-members. In all, 404 (61\%) surveys were returned. Only a few items on some responses were not usable. The responses came from 214 (53\%) AACSB member schools and 190 (47\%) nonmembers. Of these, $262(65 \%)$ of the schools classified their mission as liberal arts while 142 (35\%) classified their mission as either comprehensive education or research.

The current requirements for foreign language study for colleges which responded to our survey are shown in Table 1 and indicate 220 (54\%) of these schools do not require any business major to take a foreign language; 99 (25\%) specify that all undergraduate business majors take language courses; 85 (21\%) designate that only some specific business majors are required to study a foreign language. The percentage of schools not requiring business students to take a foreign language class (54\%) has not changed since the 1998 study of Rogers and Arn.

The survey also questioned the deans about the requirement for foreign language study for their graduate students. Of the colleges responding to our survey, 264 also had graduate programs. Of these, 251 (95\%) did not require foreign language courses for any of their graduate students; $13(5 \%)$ required foreign language of some of their graduate students. No school required it of all its graduate business students. 
Table 1: Foreign Language Requirements in Schools

\begin{tabular}{|l|c|c|c|c|c|c|}
\hline & \multicolumn{2}{|c|}{ AACSB } & \multicolumn{2}{c|}{ Non-AACSB } & \multicolumn{2}{c|}{ Total } \\
\hline Policy of school & No & $\%$ & No. & $\%$ & No. & $\%$ \\
\hline Does require foreign language & 45 & 21 & 50 & 29 & 95 & 25 \\
\hline Requires foreign language for some & 49 & 23 & 36 & 19 & 85 & 21 \\
\hline Does not require foreign language & 120 & 56 & 97 & 53 & 220 & 54 \\
\hline
\end{tabular}

\section{AACSB Members and Non-Members}

The results changed little when the sample was divided into schools which had attained AACSB accreditation and non-member schools. As shown in Table 1, 120 (56\%) of AACSB member schools did not require language of any business major; 45 (21\%) required it of all business majors; 49 (23\%) required it of only some business majors. For non-member schools, the results were similar with 97 (53\%) not requiring a language for any business major; 40 (29\%) required it of all majors; 36(19\%) requiring some majors to take language courses. Interestingly, non-AACSB schools actually had a slightly higher rate of students required to take a different language than did member schools.

Of the Schools with a language requirement, 152 required a full year of study; 10 schools only required one course while 22 schools required more than one year of study.

Typically, at the schools which required a foreign language, any language taught there would satisfy the requirement. Spanish, French, and German were the most common languages offered.

In 1998, the Rogers and Arn survey found that $71 \%$ of deans believed there was a need for a foreign language requirement. In our survey, as shown in Table 2, the results were even stronger with $90 \%$ of the deans indicating that studying a foreign language would be very helpful or somewhat helpful to their student's careers. $52 \%$ thought it to be very helpful; 38\% considered foreign language study somewhat helpful; $9 \%$ were neutral; only $1 \%$ believed language study not very helpful at all. Deans at both member (89\%) and non-member colleges (90\%) thought language study to be very helpful or somewhat helpful to a student's career.

Table 2: Deans' Opinions on Benefit of Foreign Language Study

\begin{tabular}{|l|c|c|c|c|c|c|}
\hline & \multicolumn{2}{|c|}{ AACSB } & \multicolumn{2}{c|}{ Non-AACSB } & \multicolumn{2}{c|}{ Total } \\
\hline & No. & $\%$ & No. & No. & \% \\
\hline Very Helpfu & 105 & 49.8 & 102 & 53.3 & 207 & 51.8 \\
\hline Somewhat Helpful & 83 & 39.3 & 70 & 36.6 & 153 & 37.9 \\
\hline Neutral & 20 & 9.5 & 16 & 8.4 & 36 & 8.9 \\
\hline Not very helpful & 2 & 0.9 & 3 & 1.6 & 5 & 1.2 \\
\hline Not helpful at all & 1 & 0.5 & 0 & 0 & 1 & 0.2 \\
\hline
\end{tabular}

Deans are the administrative leaders of the Business Schools and often drive decisions on curriculum. To determine if there was a relationship between the attitude of the dean toward the need for foreign language study and the language requirement at his or her college, a correlation coefficient was calculated. The test statistic $(r=.08)$ indicated a statistically insignificant relationship. On the other hand, as shown in Table 3, of the schools which classified themselves as having a liberal arts mission, 54\% required language of all or some of their business majors versus only $29 \%$ for those having a research or comprehensive mission. A statistically significant positive correlation (.72) exists between schools which have a liberal arts mission and the presence of a foreign language requirement for business students at these schools. 
Table 3: Language Requirements and School Mission

\begin{tabular}{|l|c|c|}
\hline & Liberal Arts & Comprehensive/Research \\
\hline Does Require Foreign Language & $32 \%$ & 11 \\
\hline Requires Foreign Language for Some & $22 \%$ & $18 \%$ \\
\hline Does not Require Foreign Language & $45 \%$ & $71 \%$ \\
\hline
\end{tabular}

\section{CONCLUSION}

In 1998, most business school deans thought that the requirement for business students to study a foreign language was a good idea. Today, $90 \%$ of the deans surveyed still share this view. Regretfully, these attitudes have not been translated into enhanced language requirements. Importantly, the percentage of colleges with foreign language requirements for business students has not changed in almost a decade. This finding is consistent between colleges accredited by the AACSB and non-member schools. In fact, business students who attend non-AACSB schools have a slightly greater chance of being required to study a foreign language. AACSB accreditation and the dean's attitude toward foreign language study seem to have little or no impact on the foreign language requirements.

\section{RECOMMENDATIONS} Arn (1998).

Based on previous research and this study, we again recommend many items first proposed by Rogers and

1. AACSB members that do not currently have a foreign language requirement should adopt one. Many states now require a fifth year of study before an Accounting major is eligible to sit for the CPA exam. Thus, AACSB accredited Accounting programs should take the lead and promote foreign language studies within the fifth year for their majors.

2. The AACSB should consider mandating a foreign language requirement for business students. Historically, the AACSB has been a leader in bringing new topics into the business curriculum. For example, many schools teach a specific course in Business Ethics due to accreditation standards. Widespread implementation of foreign language requirements may never occur without the firm support of the AACSB.

3. Students should be advised early in their college career about the usefulness of foreign language study. Students may wish to take these courses as electives even if they are not required by their college.

\section{REFERENCES}

1. Guy, B. (1992). Dismantling self-imposed trade barriers revisited: the role of language development ten year later. Paper presented at the meeting of the Annual Eastern Michigan Conference on Languages and Communication for World Business and the Professions, Ypsilanti, MI.

2. Johnson, D. (1993). Global marketing education. Marketing Education Review, 3(1). 51. Koch, D. (1995). Foreign language in MBA programs: A report on a survey of MBA directors. (ERIC Document Reproduction Service No. ED355843).

3. The President's Commission on Foreign Language and International Studies, Strength Through Wisdom: A Critique of U.S. Capability (Washington, DC: U.S. Government Printing Office, 1979). 28.

4. Radebaugh, L. \& Shields, J. (1984). A note on foreign language training and international business education in US colleges and universities. Journal of International Business Studies, 15. 195-99.

5. Rogers, B. \& Arn, J. (1998). Language requirements for baccalaureate degrees in AACSB-accredited schools: deans' opinions. Journal of Education for Business, 73(6). 347-50.

6. Slonaker, W. \& Cannon, E. (1992). Internationalizing the business professor: a collaborative effort. Paper presented at the meeting of Annual Eastern Michigan Conference on Languages and Communication for World Business and Professions, Ypsilanti, MI.

7. Timpe, E. (1998). Which languages are going to be of most importance for business by the year 2000. Paper presented at the meeting of the Annual Eastern Michigan Conference on Languages and Communication for World Business and Professions, Ypsilanti, MI.

8. U.S. Census Bureau. (2003). Census 2000. Summary File 3, Table PCT 10, released Feb. $25,2003$. 